\title{
DAMAGE RATIOS FOR HOUSES AND MICROZONING EFFECTS IN NAPIER IN THE MAGNITUDE 7.8 HAWKE'S BAY, NEW ZEALAND EARTHQUAKE OF 1931
}

\author{
D.J. Dowrick ${ }^{1,3}$, D.A. Rhoades' ${ }^{2}$, J. Babor ${ }^{1}$ \\ and R.D. Beetham ${ }^{1,4}$
}

\begin{abstract}
This paper describes the analysis of a large data base of actual costs of damage to houses in Napier in the magnitude $M_{S}=7.8$ Hawke's Bay earthquake of 1931 . This event occurred prior to the introduction of any earthquake design regulations in New Zealand. The town of Napier was sited over the source of this large shallow event, and therefore it may be presumed that it was subjected to about the strongest shaking likely to occur in an earthquake. Mean values and statistical distributions of damage ratios have been estimated for houses built on rock, on firm beach deposits, and on soft recent alluvium. This is the first time world-wide that a fully representative quantification of damage has been made for a zone of such strong earthquake shaking, for any class of construction, with or without quantification of microzoning effects. This study examines the damage to housing due to ground shaking and ground damage, and excludes the effects of earthquake-induced fires.
\end{abstract}

\section{INTRODUCTION}

The damaging Hawke's Bay, New Zealand, earthquake which occurred at 10.42 am (LT) on the 3rd February, 1931 had a magnitude of $\mathrm{M}_{S}=7.8[1,2]$ and $\mathrm{M}_{\mathrm{W}}=7.7-7.8$ [3]. It was a predominantly thrust event with a ratio of reverse to strike-slip component of c.1.0 [3]. The rupture surface was adjacent to the two largest towns in Hawke's Bay, Napier and Hastings (Figure 1). Its large source is considered [3] to have started on the subduction interface, with the primary fault rupture extending from about $30 \mathrm{~km}$ depth to within about $5 \mathrm{~km}$ of the surface, and the surface manifestations included fault scarps up to about $4.5 \mathrm{~m}$ high which were probably secondary ruptures. In the 1930's, three papers [4-6] were published describing damage to houses in the earthquake, but the present paper is the first to examine the damage in modern earthquake engineering terms.

Damage is most readily quantified in terms of a damage ratio, i.e.

$$
\mathrm{D}_{\mathrm{r}}=\frac{\text { Cost of damage to a house }}{\text { Value of the house }}
$$

The damage ratio is a function of the intensity of shaking.

Representative data sets adequate for deriving reliable damage ratios have arisen very rarely on a world-wide basis. To date,

\footnotetext{
1 Institute of Geological \& Nuclear Sciences, Lower Hutt

2 Industrial Research Ltd, Lower Hutt

${ }^{3}$ Fellow ${ }^{4}$ Member
}

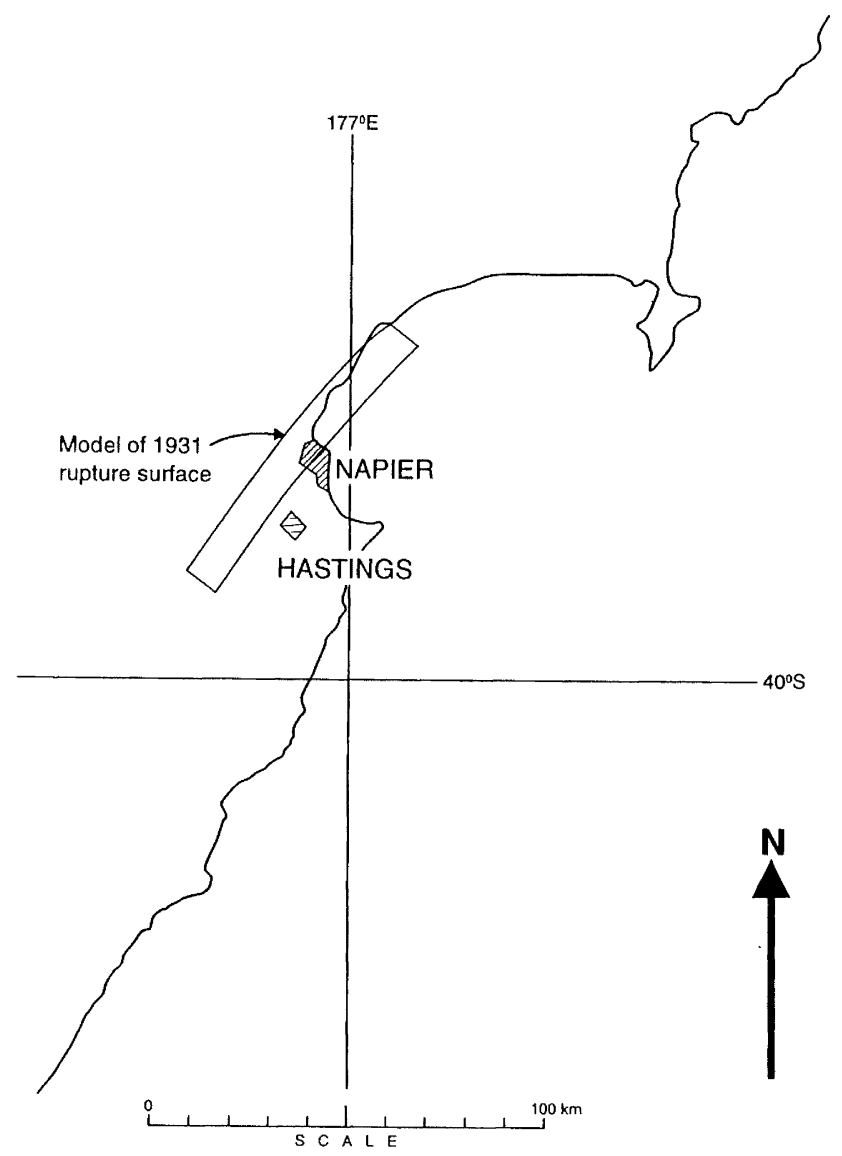

FIGURE 1 Vertical projection of the modelled extent of the fault rupture for the 1931 Hawke's Bay earthquake (after [3]). 
the 1987 Edgecumbe New Zealand earthquake is the only earthquake in the world for which a comprehensive data set has been assembled and analysed. Results of studies of the Edgecumbe data have been published [7-9] for houses, house contents and commercial and industrial property, with a further paper yet to come. The Edgecumbe earthquake was of magnitude $M_{S} 6.6$ and $M_{W} 6.4$, and was shallow with surface fault rupturing, giving a maximum intensity zone of MM9 (Modified Mercalli intensity IX). That earthquake enabled good definitions of damage ratios and their distributions to be obtained for the first time world-wide, thus considerably enhancing the engineering and risk interpretations of damage levels at intensities up to MM9. There is still a great need for more good damage ratio data from other earthquakes, affecting other building stocks, and particularly data from the zone of strongest shaking (MM10) at the centre of major earthquakes. Hence it is of great significance that an excellent set of damage cost data was recently found to exist for houses in Napier from the 1931 Hawke's Bay earthquake. Fortuitously Napier had a wide range of soil and topographical conditions within its borough boundary, making possible a particularly richly detailed series of studies.

\section{STRENGTH OF SHAKING IN NAPIER}

The strength of shaking in Napier in this event was very great as demonstrated by the considerable damage to the built and natural environments both in and near Napier $[10,11]$. Existing isoseismal maps for this earthquake show Napier located in an MM10 zone. However these maps use either Rossi-Forel (RF) or approximate MM intensities (derived by conversion from RF data). Information being assembled in the current preparation of a true MM isoseismal map [12] suggests that intensity MM10 will be hard to justify strictly in accordance with the criterion of "most masonry structures destroyed" (because of the relatively high quality of such buildings in Napier). However the two New Zealand attenuation expressions for intensity [13, 14] both model Napier as being well within an MM10 zone.

In addition, although no strong-ground motion records exist from this event, attenuation expressions based on both New Zealand and foreign data suggest that peak ground acceleration on bedrock must have been in the region of $1.0 \mathrm{~g}$ in Napier, i.e. immediately over the source of a magnitude 7.8 reverse faulting earthquake. This acceleration is so much higher than that normally associated with MM9 (PGA $=0.4-0.5 \mathrm{~g}$ ) that a higher level of intensity is implied (i.e. MM10).

Thus it seems appropriate to assume that Napier was in an MM10 zone in 1931.

\section{THE DATA}

The two main repositories of material on the 1931 Hawke's Bay earthquake are the Hawke's Bay Museum in Napier and the Alexander Turnbull Library in Wellington, the holdings in the latter being mainly photographs. In October 1992 Dowrick visited the library of the Hawke's Bay Museum to examine its holdings. As well as information in a few books and an excellent collection of photographs, he was amazed to find in the non-public stack room a set of about 50 box files full of documents describing damage to buildings. These documents were mostly of two types, namely relating to:

(i) Applications for loans from the Hawke's Bay Earthquake Relief Fund for the repair of houses (Loans); and

(ii) Applications for permits to re-occupy buildings (Reoccupation).

The documents relating to loans comprised the following:

- An Application Form, giving address of house, owner's and occupier's name(s), owner's valuation of house building, number of (non-service) rooms.

- A Damage Cost Form, giving builder's estimates (actually quotes) for repairs itemised under different trades, etc.

- A Building Inspector's Report on the nature of the damage and the validity of the costs

- Correspondence detailing final costs, etc.

- Card files summarizing the data for each application (one card per application).

Our most important computer database for Napier has been developed from these loans documents, and it contains damage costs for 2260 houses (about two-thirds of the total number of houses in Napier in 1931). As can be seen, repair costs were given under seven specified official headings, with other headings being specified by the house owner where appropriate. A broad breakdown of the total costs under these headings is given in Table 1

TABLE 1 Breakdown of Damage Costs in Loans Database

Total Costs of Damage

Chimneys
Tanks and stands
Plumbing
Drains
Lighting
Carpentry
Glazing
Decorating
Unspecified
Other
Total

Notes: (1) Full decorating costs have been estimated as $£ 20,000$ as discussed in the text.

(2) This total excludes costs of 14 houses totally written off and does not include modernisation of decorating costs added in analysis Series C.

Data on the nature of the houses, their sites, and the damage, supplementing that which is in the database, has been obtained partly from the loans documents and also from field trips, maps and other sources. The repair costs in our database differ from 
those for which loans were given in a number of respects, namely:

(i) Loans were available for approved repairs up to a cost of $£ 100$. We have included the full cost of repairs, which exceeded $£ 100$ in 213 houses in our data set.

(ii) Loans did not extend to repairs of wallpapering or paintwork (although this rule was not uniformly enforced). We have included all such costs where given (see further discussion later).

(iii) Loans sometimes included repair costs for fences and gates. We have excluded such costs.

(iv) Loans were usually not given for repairs paid for prior to the inspector's visit. Where such costs were evidently genuine, according to the inspector, these have been included in our data set.

(v) Loans were not given in a number of instances where houses had been damaged to a cost of much more than $£ 100$. Such data has been included where evidently genuine, including 14 houses known to have been totally beyond repair (by causes other than earthquake-induced fire) and for which no loan application was made (see Section 8).

(vi) In a number of cases loan applications were only for the repair of drains. Where the Re-occupation reports gave information that other damage had occurred, allowances for such damage costs have been included.

The documents relating to Re-occupation of each house comprised:

- An Application Form, giving the address of the building, and the owner's and/or occupier's names.

- A Building Inspector's Report, on the safety of the building for occupation, and sometimes with supplementary information on the nature and likely cost of damage.

- A Sanitary Inspector's Report, on the fitness of the building for occupation, and sometimes with supplementary information on the nature and likely cost of damage.

Our computer database derived from the Re-occupation documents contains information relating to 2648 houses

\section{GENERAL DESCRIPTION OF HOUSES AND DAMAGE IN NAPIER}

At the time of the earthquake there were c. 3400 houses in the Borough of Napier. Of these c. 3250 were timber framed with weather-board cladding, c. 45 were of brick bearing wall construction, and a few were made of concrete. These figures were obtained by starting with the data in the 1926 Census and adding the annual building permit increments up to December 1930. Due to natural attrition, a small number of houses are likely to have been demolished between 1926 and 1931, perhaps between 5 and 10 per year (R. Calderwood, Valuation New Zealand, pers. comm. 1994)
Based on our sample of 2260 houses, c. $83 \%$ were plain singlestoreyed, 7\% were single- storeyed with partial basements, and $10 \%$ were 2 -storeyed (all but seven of which were without basements). Almost all houses had at least one chimney, mostly made of unreinforced brick.

All the contemporary reports comment on how little damage was done to houses, excepting their chimneys. For example, Dixon [4] noted that "practically all old wooden buildings, including houses, shops and public buildings, were still intact after the earthquake", and that "well over 90 percent suffered no other damage than that resulting from falling chimneys". According to Dixon the three most important causes of damage relating to timber construction itself, were:

(1) Lack of anchorage of the superstructure to the foundations,

(2) Lack of bracing of sub-floor framing or jack studding (piles), and

(3) Inefficient bracing of wall panels in buildings of two or more storeys.

A little later Brodie and Harris [6] noted that "solidly constructed wooden buildings stood the shock well. The chief source of trouble was the foundation, particularly where the subsoil was silt and there was considerable earth-movement". They also noted the above causes of damage given by Dixon, and added that "many of the concrete foundations were not reinforced, and numerous cases of destruction of this type of foundation were observed".

Discussing buildings with brick bearing walls, Brodie and Harris [6] noted that "there were many examples of brick dwellings of one or two storeys which suffered practically no damage, and several examples of failure can be attributed to unsuitability of the site - e.g. in Napier a house on the edge of Bluff Hill face, and another on the high spur at the other end of Scinde Island" (i.e. Hospital Hill).

The above general remarks are confirmed by many other sources, including contemporary newspaper reports, and oral comments from past and present Napier citizens obtained during the course of the present study. Arising from our statistical analyses, more discussion on the nature of the damage is given later in this paper.

\section{DAMAGE RATIOS}

\subsection{Damage ratios for houses}

The damage ratio for each house was found using equation (1), where the Value of the house was taken to be the Owner Valuation as given in the Applications for Loans. The Owner Valuation appears to equate to Replacement Value as the mean Owner Valuation was $£ 882$, and the average cost of building a house in Napier in the period 1926-1930 was $£ 892$.

Our interest here is in finding the mean damage ratios and statistical distributions for various subsets of the houses in Napier, i.e. in the MM10 intensity zone of the earthquake. As described elsewhere [9], mean damage ratios estimated using two different definitions are of interest. Firstly, 


$$
\bar{D}_{r}=\frac{\sum_{i=1}^{n}[\text { cost of damage to building } i]}{\sum_{i=1}^{N} \text { [value of building i] }}
$$

where $\mathrm{n}$ is the number of damaged buildings, and $\mathrm{N}$ is the total number of buildings (damaged and undamaged) in the relevant population. Secondly,

$$
D_{\mathrm{rm}}=\frac{\sum_{\mathrm{i}=1}^{n}\left[\mathrm{D}_{\mathrm{r}_{\mathrm{i}}}\right]}{\mathrm{N}}
$$

where the $\mathrm{D}_{\mathrm{ri}}$ are the damage ratios for individual buildings.

If derived from representative populations, $\bar{D}_{\mathrm{r}}$ is correct for finding total losses for large populations of any type of property. For relatively homogeneous populations such as houses or household contents, $\vec{D}_{r}$ and $D_{r m}$ tend to be similar in value. The more inhomogeneous a given population is, the more $\bar{D}_{r}$ and $D_{r m}$ may differ [9]. In general, $\mathrm{D}_{\mathrm{rm}}$ with its associated probability distribution is a more reliable and useful tool than $\mathrm{D}_{\mathrm{r}}$.

We have estimated the above means and their associated distributions and statistical parameters for various subsets of the data as described below.

\subsection{Repair Cost Basis}

First we carried out a series of analyses using all the repair cost data available from the 1931 documents, without differentiating between ground conditions. The subsets of data considered were as follows:

\section{A1 Total database}

A2 As A1, but excluding cost of repair to drains.

A3 Single-storey timber houses, excluding those damaged by landslides.

A4 Single-storey timber houses with partial basements (i.e. those on sloping ground), excluding those damaged by landslides.
A5 Two-storey timber houses including those with partial basements, excluding those damaged by landslides.

A6 Unreinforced masonry (URM), excluding those damaged by landslides.

A7 All timber houses damaged by landslides from above (not those undermined).

A8 Timber houses only, all storey heights included (i.e. one and two-storeys with and without basements).

Subsets A3 to A8 all include the costs of repairs to drains. The results of these analyses for $D_{r m}$ and $\mathrm{Dr}$ are given in the final two columns of Table 2. Salient features of the results are:

- For timber houses, single-storey houses with partial basements (A4) were the most heavily damaged, being $26 \%$ worse than plain single-storey (A3), and $30 \%$ worse than two-storey houses (A5). Two-storey houses performed slightly better than single-storey houses when costs of drains are included, but this situation reverses when drain damage is excluded (see later).

- URM houses (A6) were much more heavily damaged than timber-framed houses. However our sample size is too small for the estimated parameter values for URM houses to be very reliable.

\subsection{Effects of Ground Condition (Microzoning)}

In 1931 the Borough of Napier was limited to the area shown in Figure 2, being almost an island connected to the mainland only by a narrow spit of beach sand and gravel deposits. At this stage, based on available surface and subsurface information, three general classes of ground materials can be established for the Napier area immediately prior to the earthquake. These classes of ground materials are broadly similar to those described in the New Zealand Loadings Standard for buildings, NZS4203:1992 [15] as rock or very stiff soil, intermediate soil, and flexible or deep soil, and those described in the recent study [16] of ground shaking hazard zones in the Wellington region. The classes for Napier are:

TABLE 2 Analysis Series A

Napier loans data parameter estimates. A: Existing data (1931 repair basis)

\begin{tabular}{||l|c|c|c|c|c|c|c|c|c||}
\hline & & $\mathrm{n}$ & $\mu$ & $\sigma$ & $\sigma$ & $\gamma$ & $\delta$ & $\mathrm{D}_{\mathrm{rm}}$ & $\overline{\mathrm{D}}_{\mathrm{r}}$ \\
\hline Total Database & $\mathrm{A} 1$ & 2260 & -2.84 & 0.553 & 0.744 & 0.0768 & 0.859 & 0.0794 & 0.0715 \\
\hline Total Database, excluding drains costs & $\mathrm{A} 2$ & 2260 & -3.21 & 0.835 & 0.914 & 0.0612 & 1.14 & 0.0607 & 0.0569 \\
\hline $\begin{array}{l}\text { 1-storey timber, excl. those damaged by } \\
\text { landslides }\end{array}$ & $\mathrm{A} 3$ & 1643 & -2.86 & 0.420 & 0.648 & 0.0704 & 0.723 & 0.0703 & 0.0613 \\
\hline $\begin{array}{l}\text { 1-st. timb., with partial basements, excl. } \\
\text { those damaged by landslide }\end{array}$ & $\mathrm{A} 4$ & 137 & -2.79 & 0.683 & 0.827 & 0.0869 & 0.990 & 0.0885 & 0.0778 \\
\hline $\begin{array}{l}\text { 2-st. timb., excl. those damaged by } \\
\text { landslide }\end{array}$ & $\mathrm{A} 5$ & 187 & -2.94 & 0.472 & 0.687 & 0.0670 & 0.776 & 0.0683 & 0.0589 \\
\hline $\begin{array}{l}\text { Unreinforced masonry, excl. those } \\
\text { damaged by landslide }\end{array}$ & $\mathrm{A} 6$ & 21 & -1.91 & 3.80 & 1.95 & 0.992 & 6.62 & 0.507 & 0.526 \\
\hline $\begin{array}{l}\text { Timber houses damaged by landslides } \\
\text { from above }\end{array}$ & $\mathrm{A} 7$ & 42 & -1.81 & 0.661 & 0.813 & 0.227 & 0.968 & 0.222 & 0.169 \\
\hline All timber houses & $\mathrm{A} 8$ & 2227 & -2.85 & 0.495 & 0.704 & 0.738 & 0.800 & 0.0748 & 0.0652 \\
\hline
\end{tabular}




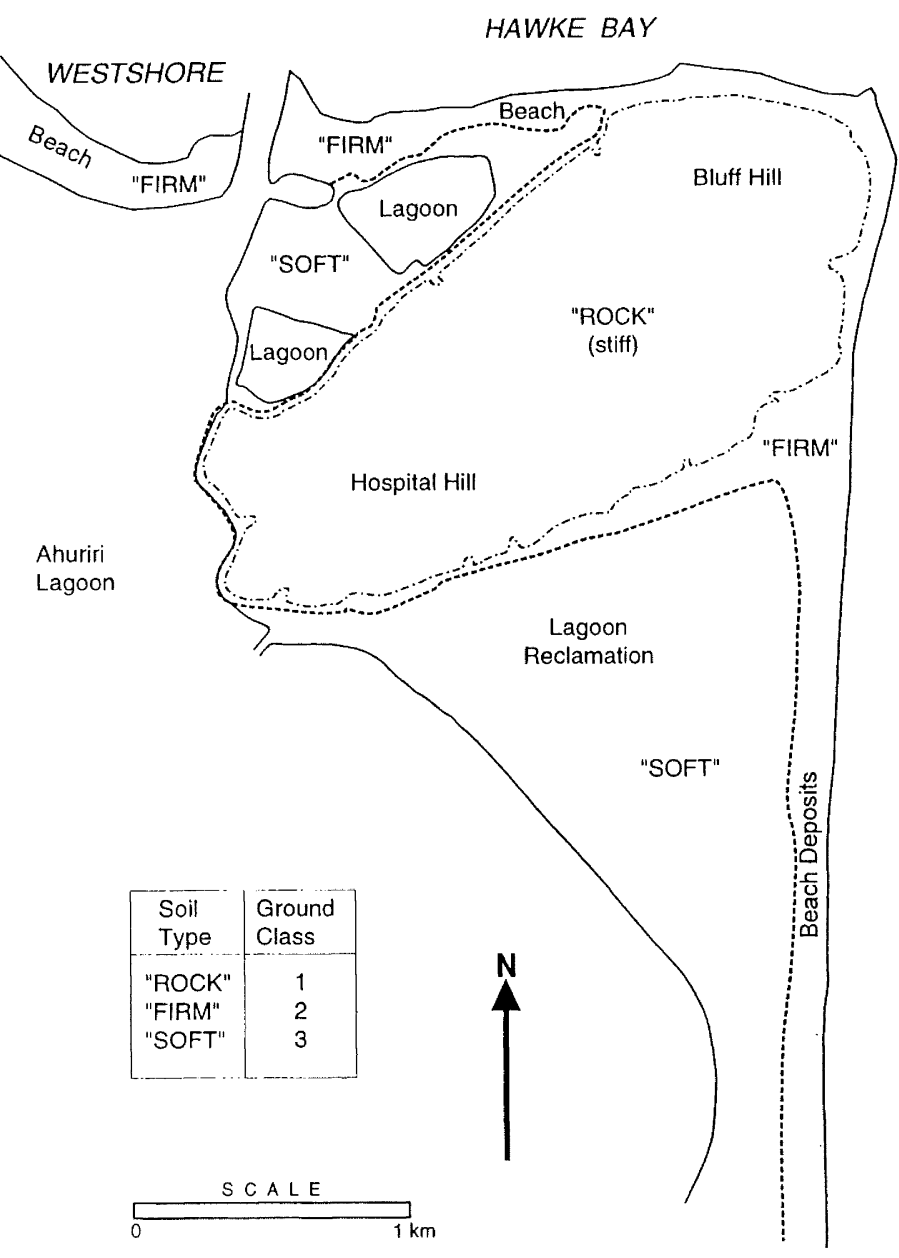

FIGURE 2 Simplified ground class map of 1931 Napier.

\section{Description}

1 Early Quaternary marine sediments (very compact silts, sands, and limestones) of Mataruahou (Scinde Island) and the other hills and former islands to the west. Mataruahou itself is predominantly made up of cemented limestone. These marine sediments are effectively 'bedrock' in this area and are likely to act as a stiff, dense rock material during strong earthquake shaking.

2 Dense sands and fine-medium gravels of the sand spits. These materials are classed as 'firm ground'. The top 5-10 m at least, are likely to comprise very dense sands and gravels deposited in a high energy beach environment. Experience with similar materials indicates that they will exhibit SPT $N$ values $\geq 50$, and are unlikely to show ground damage due to high intensity (MM10) shaking.

3 Reclaimed swamp and lagoon areas. These are classed as 'soft ground' and are likely to vary both laterally and with depth, and to consist predominantly of interlayered mixes of poorly consolidated, saturated, fine grained soils (muds) and organic material with peat horizons to moderate depths (possibly up to $30 \mathrm{~m}$ or more).
These classes of ground could be expected to show different responses to shaking, and structures constructed on them might also be influenced in different ways depending on the type of structure and its construction. Once more detailed subsurface information is available, it is possible that further categories of ground may be able to be defined, and the present boundaries between the zones may be modestly revised. A more detailed microzoning study is being planned.

Our initial microzoning study, presented briefly here, divides the town into the above three ground classes, and also considers a subdivision of the soft ground into sites with and without ground damage. So as to make the results for the different ground classes as comparable as possible, the analyses were restricted to timber houses not damaged by landslides. The subsets of that data considered were as follows:

B1 (a) Single-storey houses, all costs included, divided into the three ground classes $(1,2,3$, i.e. rock, firm and soft).

(b) Two-storey houses, all costs included, divided into the three ground classes.

B2 (a) As B1(a), but excluding costs of drains.

(b) As B1(b), but excluding costs of drains.

(c) Single-storey houses, excluding costs of drains, on soft ground without ground damage (designated B2(a)3-G in Table 3).

(d) Two-storey houses, excluding costs of drains, on soft ground without ground damage (designated B2(b)3-G in Table 3).

B3 (a) Single-storey houses on sites with Ground Damage, $\mathrm{G}$ (significant subsidence and/or ground cracking), all costs included.

(b) Single-storey houses on sites with ground damage, $G$, excluding costs of drains.

The results of these analyses are given in Table 3. Salient features of these results are:

- The structural damage (i.e excluding drains) to singlestorey houses increases with increasing ground stiffness, i.e. it is worst on rock and least on the soft ground without Ground Damage (Figure 3). This implies that there is attenuation of short-period shaking, rather than amplification, on soft ground in large amplitude shaking. But because topographic effects on the hill may have amplified the ground motion at many of the houses on rock sites, the full significance of the rock result is unclear at present (see further discussion in Section 9 below). However the difference between the firm and soft sites is uncomplicated by topography, as all these sites are on flat land.

- The structural damage to two-storey houses is greater on the stiff ground than on firm or soft (Figure 3), although the trend is not continuous with ground stiffness as it is for single storey houses. However the numbers of twostorey houses on firm and soft sites are not large enough for these two values to be very robust. Thus the relative difference between two-storey houses on firm and soft ground is open to question. 
TABLE 3 Analysis Series B

Napier loans data parameter estimates. B: Microzoning study using existing data

\begin{tabular}{|c|c|c|c|c|c|c|c|c|c|}
\hline & & $\mathrm{n}$ & $\mu$ & $\sigma^{2}$ & $\sigma$ & $\gamma$ & $\delta$ & $D_{\mathrm{rm}}$ & $\overline{\mathrm{D}}_{\mathrm{r}}$ \\
\hline \multirow{3}{*}{$\begin{array}{l}\text { Single-storey houses, all costs included, ground classes } \\
1,2,3 \text { (i.e. "rock", "firm", "soft") }\end{array}$} & B1(a) 1 & 417 & -2.86 & 0.512 & 0.716 & 0.0737 & 0.818 & 0.0729 & 0.0662 \\
\hline & $\mathrm{B} 1(\mathrm{a}) 2$ & 281 & -2.72 & 0.478 & 0.692 & 0.0838 & 0.783 & 0.0827 & 0.0674 \\
\hline & $\mathrm{B} 1(\mathrm{a}) 3$ & 945 & -2.90 & 0.346 & 0.589 & 0.0652 & 0.643 & 0.0655 & 0.0577 \\
\hline \multirow{3}{*}{$\begin{array}{l}\text { Two-storey houses, all costs included, ground classes } \\
\text { 1, 2, } 3 \text { (i.e. "rock", "firm", "soft") }\end{array}$} & $\mathrm{B} 1(\mathrm{~b}) 1$ & 127 & -2.85 & 0.452 & 0.672 & 0.0719 & 0.756 & 0.0742 & 0.0643 \\
\hline & $\mathrm{B} 1$ (b) 2 & 25 & -3.22 & 0.473 & 0.687 & 0.0505 & 0.777 & 0.0490 & 0.0335 \\
\hline & $\mathrm{B} 1$ (b) 3 & 35 & -3.02 & 0.477 & 0.691 & 0.0617 & 0.782 & 0.0606 & 0.0523 \\
\hline \multirow{3}{*}{$\begin{array}{l}\text { Single-storey houses, excl. drains costs, ground classes } \\
\text { 1, } 2,3 \text { (i.e. "rock", "firm", "soft") }\end{array}$} & $\mathrm{B} 2(\mathrm{a}) 1$ & 417 & -3.01 & 0.494 & 0.703 & 0.0626 & 0.799 & 0.0624 & 0.0574 \\
\hline & $\mathrm{B} 2(\mathrm{a}) 2$ & 281 & -3.14 & 0.595 & 0.771 & 0.0584 & 0.901 & 0.0562 & 0.0479 \\
\hline & $\mathrm{B} 2(\mathrm{a}) 3$ & 945 & -3.47 & 0.711 & 0.844 & 0.0443 & 1.02 & 0.0407 & 0.0362 \\
\hline \multirow{3}{*}{$\begin{array}{l}\text { Two-storey houses, excl. drains costs, ground classes } \\
\text { 1, 2, } 3 \text { (i.e. "rock", "firm", "soft") }\end{array}$} & $\mathrm{B} 2$ (b) 1 & 127 & -2.99 & 0.569 & 0.754 & 0.0664 & 0.876 & 0.0679 & 0.0589 \\
\hline & $\mathrm{B} 2(\mathrm{~b}) 2$ & 25 & -3.67 & 0.850 & 0.922 & 0.0392 & 1.16 & 0.0356 & 0.0270 \\
\hline & B2(b) 3 & 35 & -3.23 & 0.452 & 0.672 & 0.0494 & 0.756 & 0.0493 & 0.0434 \\
\hline 1-st. houses on sites with ground damage & B3(a)G & 101 & -2.47 & 0.320 & 0.565 & 0.0992 & 0.614 & 0.0987 & 0.0884 \\
\hline As B3(a)G, excl. drains costs & $\mathrm{B} 3(\mathrm{~b}) \mathrm{G}$ & 101 & -2.76 & 0.513 & 0.716 & 0.0814 & 0.819 & 0.0771 & 0.0686 \\
\hline 1-st. houses, soft ground, no G, excl. drains costs & B2(a)3-G & 844 & -3.56 & 0.666 & 0.816 & 0.0396 & 0.973 & 0.0364 & 0.0321 \\
\hline 2-st. houses, soft ground, no G, excl. drains costs & $\mathrm{B} 2(\mathrm{~b}) 3-\mathrm{G}$ & 33 & -3.31 & 0.355 & 0.595 & 0.0434 & 0.653 & 0.0427 & 0.0369 \\
\hline
\end{tabular}

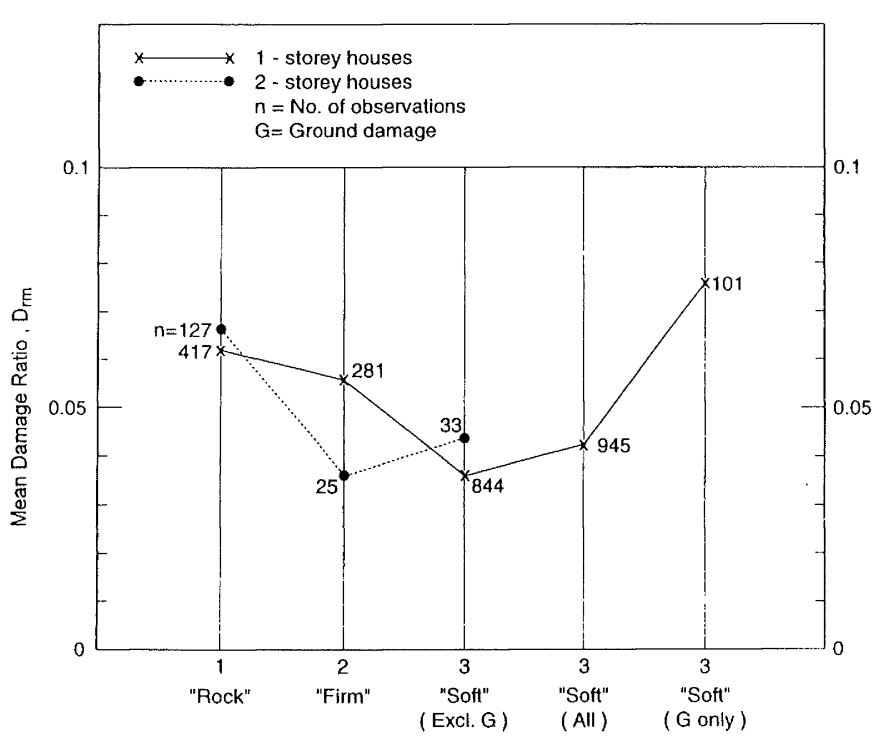

FIGURE 3 Variation of Mean Damage Ratio with ground class for timber houses, excluding costs of damage to drains and damage from landslides.

- The damage to house buildings was worst on sites with Ground Damage (Figure 3), presumably because of differential displacement of the ground rather than accelerations. In total there were 1096 houses in the soft ground (class 3 ) dataset, and of these 111 (i.e. 10\%) are known to have ground damage.

\subsection{Modernised Repair Costs}

While many pre-1931 houses exist in New Zealand today, albeit with some alterations, and most houses built subsequently have much in common with them, repairs that would be required in a modern repeat of the Hawke's Bay earthquake would differ in some ways from those used in the above two series of analyses. The chief differences would be:

(i) More decorating costs would be evident (more cost).

(ii) Fewer chimneys exist now, particularly brick ones (less cost).

(iii) Some more modern houses have better braced foundations, and are better fixed to their foundations (less cost).

(iv) Some more modern houses have more robust concrete wall foundations (less cost).

(v) Some more modern houses have larger door and window openings giving rise to more damage (more cost).

(vi) Most houses now have plasterboard internal linings instead of, or in addition to, the timber sarking prevalent in 1931. Plasterboard performs very well at suppressing racking at shaking levels somewhat greater than design level, but at very strong shaking levels, when large deflections are involved, the plasterboard can suffer brittle failure with resulting heavy damage (S Thurston, BRANZ, pers. comm., 1994) (more or less cost?).

(vii) Less costly repairs may have been made, as the owners rather than insurance companies were paying for them (less cost?). 
In this study, we have examined the effects on the damage costs of items (i) and (ii) above.

As mentioned earlier, the amounts of money loaned for repairs mostly excluded painting and papering (decorating). While these costs were declared in the Loans applications in 234 instances, it was apparent that in many cases the applicants did not declare such costs. As it is important for us to have damage ratios that reflect the full costs of house damage, we have carried out separate analyses in which we estimated the likely cost of decorating for houses where these costs were not been stated. As decorating work was mostly associated with carpentry work, for those cases where decorating costs were known the relationship between them was estimated by calculating

$$
\mathrm{k}=\frac{\text { decorating cost }}{\text { carpentry cost }}
$$

The mean value was found to be $\overline{\mathrm{k}}=0.63$.

Then for the 1496 houses having carpentry costs but no stated decorating costs, we added our estimate of

$$
\text { Decorating cost }=\overline{\mathrm{k}}[\text { Carpentry cost }]
$$

As noted above, whereas almost all houses had brittle brick chimneys in 1931, far fewer do so today. We therefore decided to examine the sensitivity of the damage ratio to the removal of varying percentages of the direct chimney costs from the database. Note that this under-estimates the true cost of chimney damage because a lot of the recorded carpentry costs (not readily identified) also arose from chimney damage.

In the series of statistical analyses that were carried out to investigate the decorating and chimney cost variations, the extra decorating costs described above were added to all cases and chimney repair costs were multiplied by the following factors (a) zero, (b) 0.2 , (c) 0.5 , (d) 1.0 . The analyses carried out were:

C1 Total database (cf A1 above).

C2 Total database, but excluding costs of drains (cf A2 above).

C3 Single-storey timber houses, excluding those damaged by landslides (cf A3 above).

C4 Single-storey timber houses with partial basements, excluding those damaged by landslides (cf A4 above).

C5 Two-storey timber houses, excluding those damaged by landslides (cf A5 above).

The results of these analyses are given in Table 4 . Salient features of these results are:

- The inclusion of the estimated missing decorating costs

TABLE 4 Analysis Series C

Napier loans data parameter estimates. C: Modernised costs. Decorating costs added $(k=0.633)$

\begin{tabular}{|c|c|c|c|c|c|c|c|c|c|}
\hline & & n & $\mu$ & $\sigma^{2}$ & $\sigma$ & $\gamma$ & $\delta$ & $D_{r m}$. & $D_{r}$ \\
\hline \multirow{4}{*}{ Total database (cf Al above) } & $\mathrm{Cl}(\mathrm{a})$ & 2260 & -3.12 & 0.917 & 0.958 & 0.0702 & 1.23 & 0.0682 & 0.0627 \\
\hline & $\mathrm{Cl}(\mathrm{b})$ & 2260 & -3.03 & 0.834 & 0.913 & 0.0730 & 1.14 & 0.0723 & 0.0661 \\
\hline & $\mathrm{Cl}(\mathrm{c})$ & 2260 & -2.91 & 0.681 & 0.825 & 0.0769 & 0.988 & 0.0784 & 0.0713 \\
\hline & $\mathrm{Cl}(\mathrm{d})$ & 2260 & -2.74 & 0.588 & 0.767 & 0.0866 & 0.894 & 0.0887 & 0.0799 \\
\hline \multirow{4}{*}{$\begin{array}{l}\text { Total database, excl. drains costs } \\
\text { (cf Al above) }\end{array}$} & $\mathrm{C} 2(\mathrm{a})$ & 2260 & -3.64 & 1.46 & 1.21 & 0.0545 & 1.82 & 0.0494 & 0.0481 \\
\hline & $\mathrm{C} 2$ (b) & 2260 & -3.55 & 1.35 & 1.16 & 0.0566 & 1.69 & 0.0535 & 0.0516 \\
\hline & $\mathrm{C} 2(\mathrm{c})$ & 2260 & -3.33 & 1.06 & 1.03 & 0.0608 & 1.37 & 0.057 & 0.0567 \\
\hline & $\mathrm{C} 2(\mathrm{~d})$ & 2260 & -3.08 & 0.896 & 0.946 & 0.0721 & 1.20 & 0.0699 & 0.0653 \\
\hline \multirow{4}{*}{$\begin{array}{l}\text { Single-storey timber houses, excl. those damaged by } \\
\text { landslides (cf } \mathrm{A} 3 \text { above) }\end{array}$} & C3(a) & 1643 & -3.15 & 0.710 & 0.843 & 0.0614 & 1.012 & 0.0582 & 0.0520 \\
\hline & $\mathrm{C} 3(\mathrm{~b})$ & 1643 & -3.06 & 0.621 & 0.788 & 0.0639 & 0.928 & 0.0624 & 0.0555 \\
\hline & $\mathrm{C} 3(\mathrm{c})$ & 1643 & -2.93 & 0.515 & 0.718 & 0.0690 & 0.821 & 0.0686 & 0.0607 \\
\hline & C3(d) & 1643 & -2.77 & 0.457 & 0.676 & 0.0790 & 0.761 & 0.0789 & 0.0693 \\
\hline \multirow{4}{*}{$\begin{array}{l}\text { 1-st. timber houses with partial basements, excl. those } \\
\text { damaged by landslides (cf A4 above) }\end{array}$} & $\mathrm{C} 4(\mathrm{a})$ & 137 & -3.08 & 1.17 & 1.08 & 0.0829 & 1.49 & 0.0786 & 0.0684 \\
\hline & $\mathrm{C} 4$ (b) & 137 & -2.99 & 1.13 & 1.06 & 0.0884 & 1.45 & 0.0829 & 0.0723 \\
\hline & $\mathrm{C} 4(\mathrm{c})$ & 137 & -2.85 & 0.888 & 0.942 & 0.0906 & 1.20 & 0.0894 & 0.0780 \\
\hline & $\mathrm{C} 4(\mathrm{~d})$ & 137 & -2.66 & 0.716 & 0.846 & 0.0997 & 1.02 & 0.100 & 0.0876 \\
\hline \multirow{4}{*}{$\begin{array}{l}\text { Two-storey timber houses, excl. those damaged by } \\
\text { landslides (cf A5 above) }\end{array}$} & $\mathrm{C} 5$ (a) & 187 & -3.20 & 0.7120 & 0.849 & 0.0583 & 1.03 & 0.0596 & 0.0524 \\
\hline & $\mathrm{C} 5$ (b) & 187 & -3.10 & 0.611 & 0.781 & 0.0614 & 0.917 & 0.0635 & 0.0557 \\
\hline & $\mathrm{C} 5(\mathrm{c})$ & 187 & -2.97 & 0.538 & 0.733 & 0.0672 & 0.844 & 0.0694 & 0.0607 \\
\hline & $\mathrm{C} 5(\mathrm{~d})$ & 187 & -2.80 & 0.489 & 0.700 & 0.0774 & 0.794 & 0.0791 & 0.0691 \\
\hline
\end{tabular}
Proportion of chimney costs included (a) 0 , (b) 0.2 , (c) 0.5 , (d) 1 . 
increases the mean damage ratio by $12-16 \%$, compared with the first series of analyses (A), depending slightly on which subset of the damage is considered.

The mean damage ratios for houses with zero cost directly from chimney damage are $25-30 \%$ less than those including the full chimney costs.

The subset of data $\mathrm{C} 1$ (c) in Table 4 (with $50 \%$ of houses having brick chimneys), may correspond reasonably well with a present-day population of houses in many parts of New Zealand, and so we have plotted its mean damage ratio $\mathrm{D}_{\mathrm{r}}=0.071$ on Figure 4 , together with the $D_{r}$ values for houses from the 1987 Edgecumbe, New Zealand, earthquake. It is seen that $\bar{D}_{\mathrm{r}}$ for MM10 in Napier is approximately equal to that for the MM9 zone found for the Edgecumbe area. This somewhat surprising result may imply that damage to New Zealand timber houses reaches a maximum at about intensity MM9. It is of interest to note that Steinbrugge [17] has been advocating this shape of damage ratio function for various types of building for a decade or so, albeit based on much less definitive data.

\subsection{Post-earthquake repair cost inflation}

It is well-recognised that earthquakes that cause a lot of damage may cause repair cost inflations due to shortage of repair resources. Also it is clear that the greater the damage in relation to the readily available (national) construction resources, the larger this inflation will be. Thus unless the replacement values of the properties concerned are increased in the same proportion to this repair cost inflation, the damage ratios $(\mathrm{Eq}$. 1) for a given event will be inflated accordingly. We need to be aware of this possible effect when we compare the mean damage ratio derived from different earthquakes, e.g. as for Edgecumbe and Napier on Figure 4. Although this inflation effect is hard to measure, we know that the amounts of damage in both these two earthquakes were relatively small in relation to the national construction resources. Hence it seems that this inflationary factor is effectively neutral in comparing the Napier and Edgecumbe results.

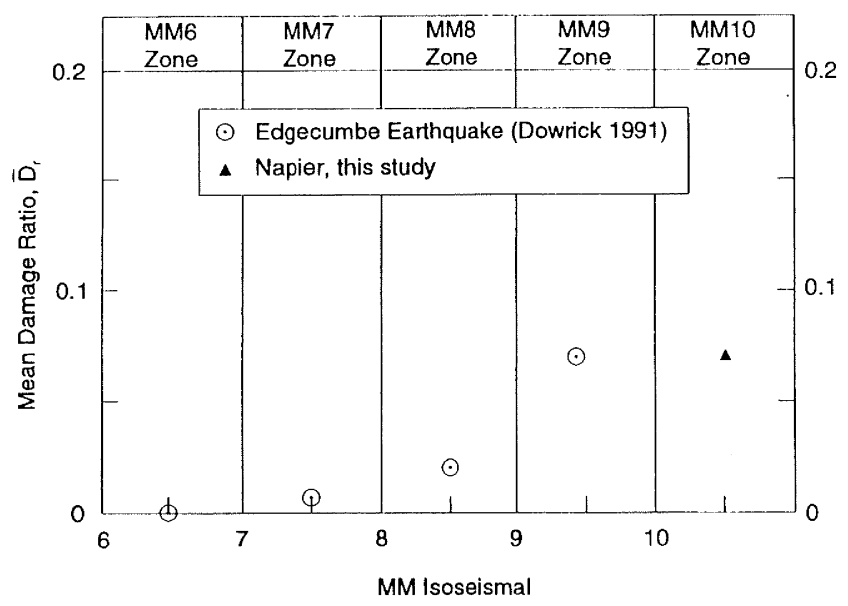

FIGURE 4 Mean damage ratios plotted as a function of intensity, as derived in this study and for the Edgecumbe earthquake [7, 8].

\subsection{Statistical distributions of damage ratios}

Recent studies by two of the present authors [7-9] apparently comprise the only published work modelling the statistical distribution of damage ratios for any class of property from real data in any given earthquake. In these studies of the 1987 Edgecumbe earthquake the damage ratios for houses, their contents, non-domestic buildings, and their contents and equipment were found to be lognormal. In the present study, the loans data set with 2600 observations is sizeable, being comparable in size to those for the houses in the inner intensity zones of the Edgecumbe earthquake.

The lognormal distribution has the density function

$$
f(x)=\frac{1}{\sigma x \sqrt{2} \pi} \exp \left[-\frac{1}{2}\left(\log _{e} x-\mu\right)^{2} / \sigma^{2}\right], \quad x>0
$$

Here the parameters $\mu$ and $\sigma$ are estimated by the sample mean and standard deviation of the natural log of the damage ratio.

The distribution has mean

$$
\gamma=\exp \left(\mu+\frac{1}{2} \sigma^{2}\right)
$$

and coefficient of variation (ratio of standard deviation to mean)

$$
\left.\delta=\sqrt{[} \exp \left(\sigma^{2}\right)-1\right]
$$

The estimates of the parameters $\mu$ and $\sigma$ (and hence $\gamma$ and $\delta$ ) found for the various data sets are given in Tables 2-4. Also tabulated are the numbers of houses $n$ in each set. As almost all houses were damaged in some way, and as our data set is representative of the total population of houses in Napier, $n$ equates closely to $\mathrm{N}$ (defined with equation (2)) for each subset.

The distribution of $\mathrm{D}_{r}$ for the total dataset (Case A1) is plotted in the form of a histogram in Figure 5. This histogram looks to be that of a lognormal distribution, and this is confirmed in the cumulative distribution plot in Figure 6 where the lognormal fit for the total data set is seen to be reasonably good. The data in the various subsets that we have considered are more homogeneous than the total data set, and for the largest of these subsets (case A3) the data is fitted almost perfectly by the lognormal distribution.

The empirical distributions of the data in the Series A subsets are plotted for visual comparison in Figure 7, and those for the subsets of Series B (the three microzoning classes) are plotted in Figure 8.

The scatter, e.g. as measured by the coefficient of variation $\delta$ in Tables 2-4, is substantially smaller than was found for houses in 1987 Edgecumbe area [8]. From the various subsets of Napier, $\delta$ lies in the range 0.65 to 1.82 , while from the Edgecumbe area, $\delta$ was in the range $2: 40$ to 2.67 . This difference may arise from the fact that the design of houses in 1931 was more uniform with far less variety of external cladding materials used (nearly all weatherboard) than was the case with the Edgecumbe housing stock.

\section{DAMAGE RATIO AS A FUNCTION OF SIZE OF HOUSE}

The possibility that damage varies with size of house has been briefly examined. In Figure $9, D_{r}$ has been plotted for one subset of houses versus the values of the houses, and a best fit 


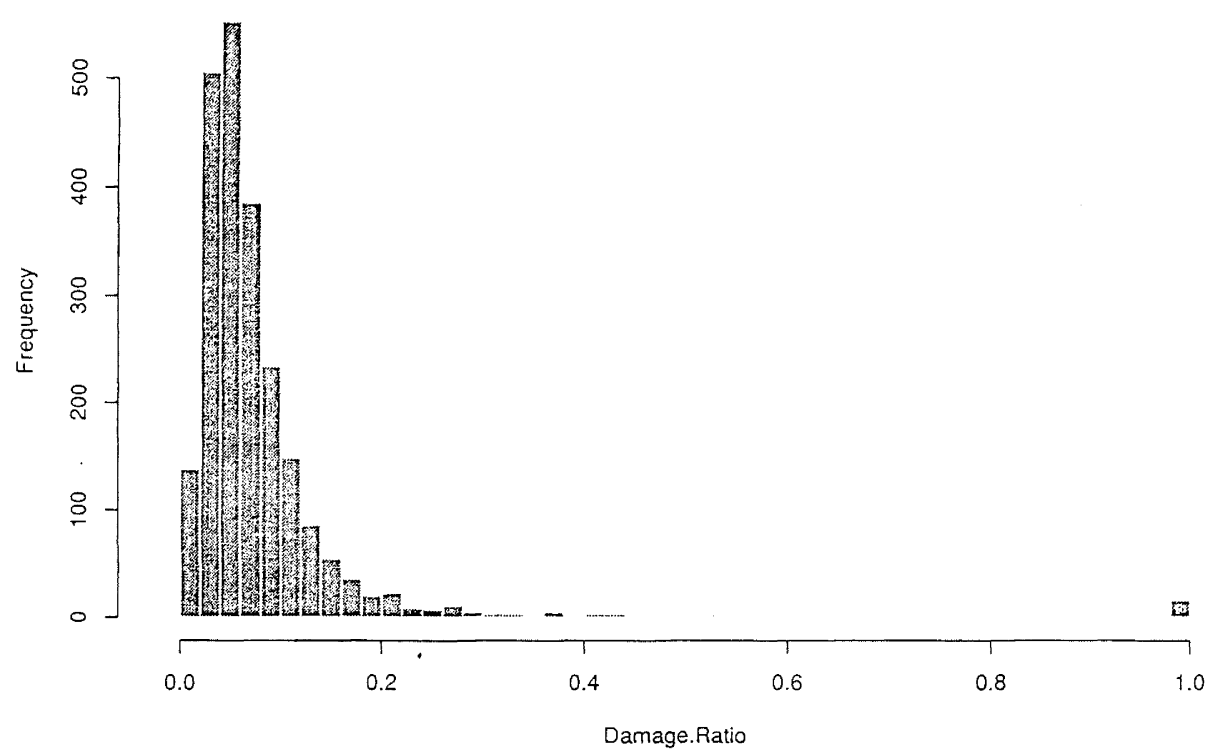

FIGURE 5 Histogram of damage ratios for houses in Napier in the 1931 Hawke's Bay earthquake, using the complete data set.

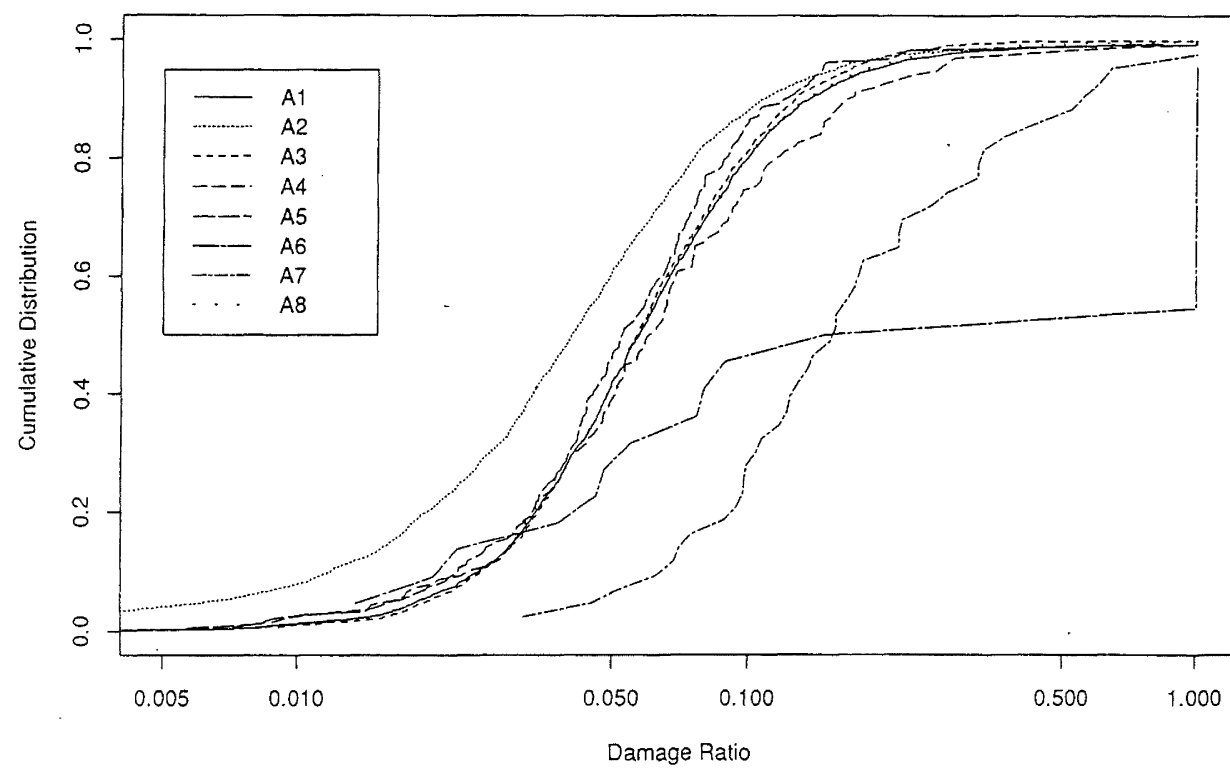

FIGURE 7 Comparison of empirical damage ratio probability distributions for various subsets of the Napier data. For key see Table 2.

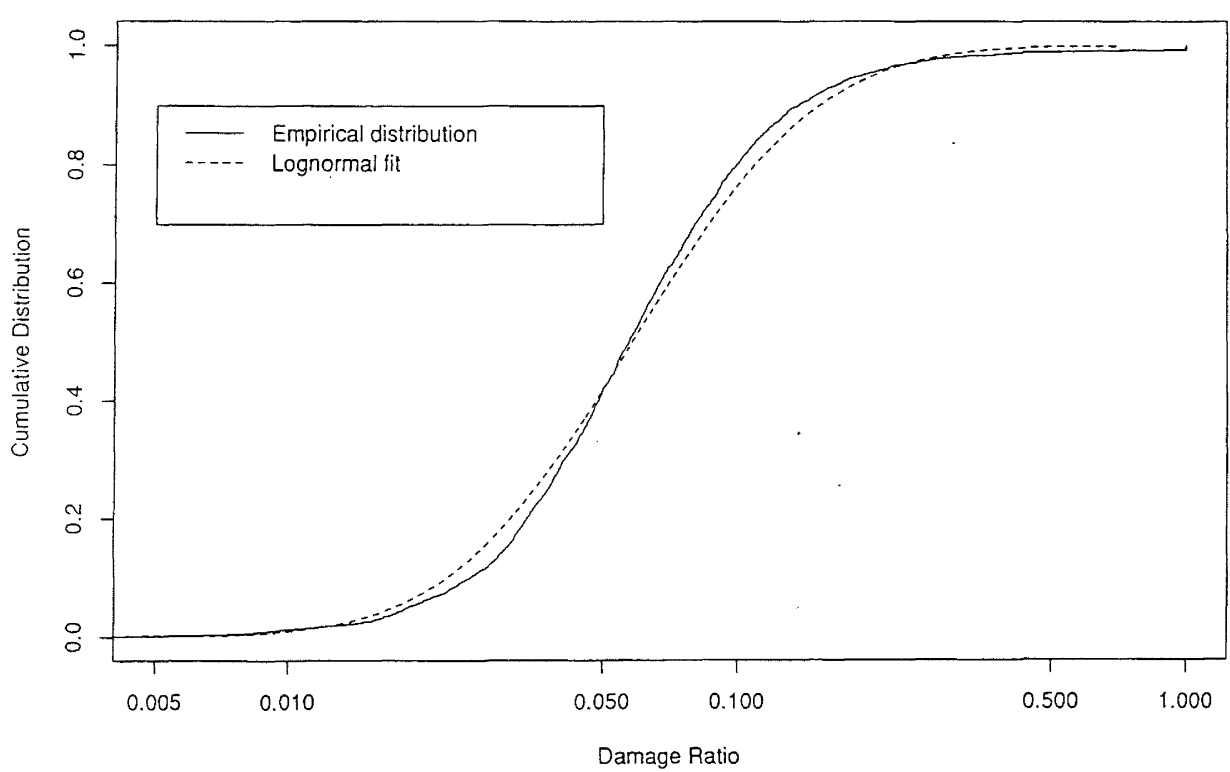

FIGURE 6 Empirical and fitted lognormal probability distribution for houses using data from Figure 5.

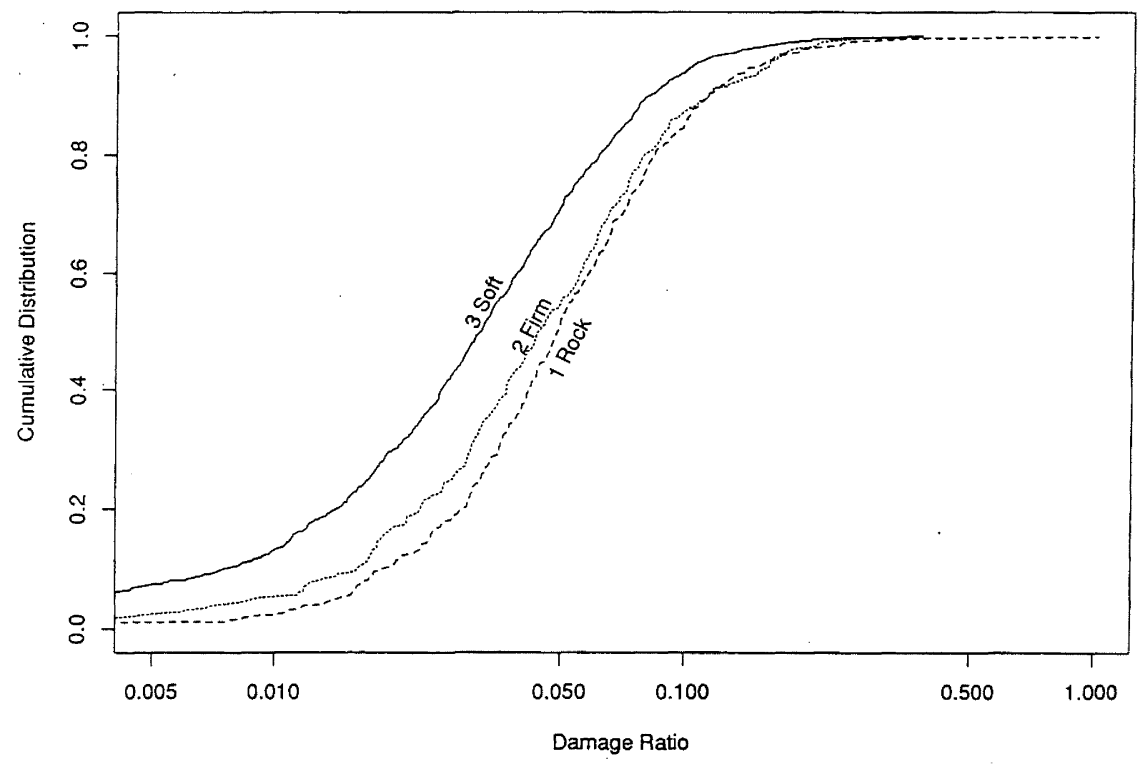

FIGURE 8 Comparison of empirical damage ratio probability distributions for single storey timber houses in the three ground class zones in Napier in 1931. 


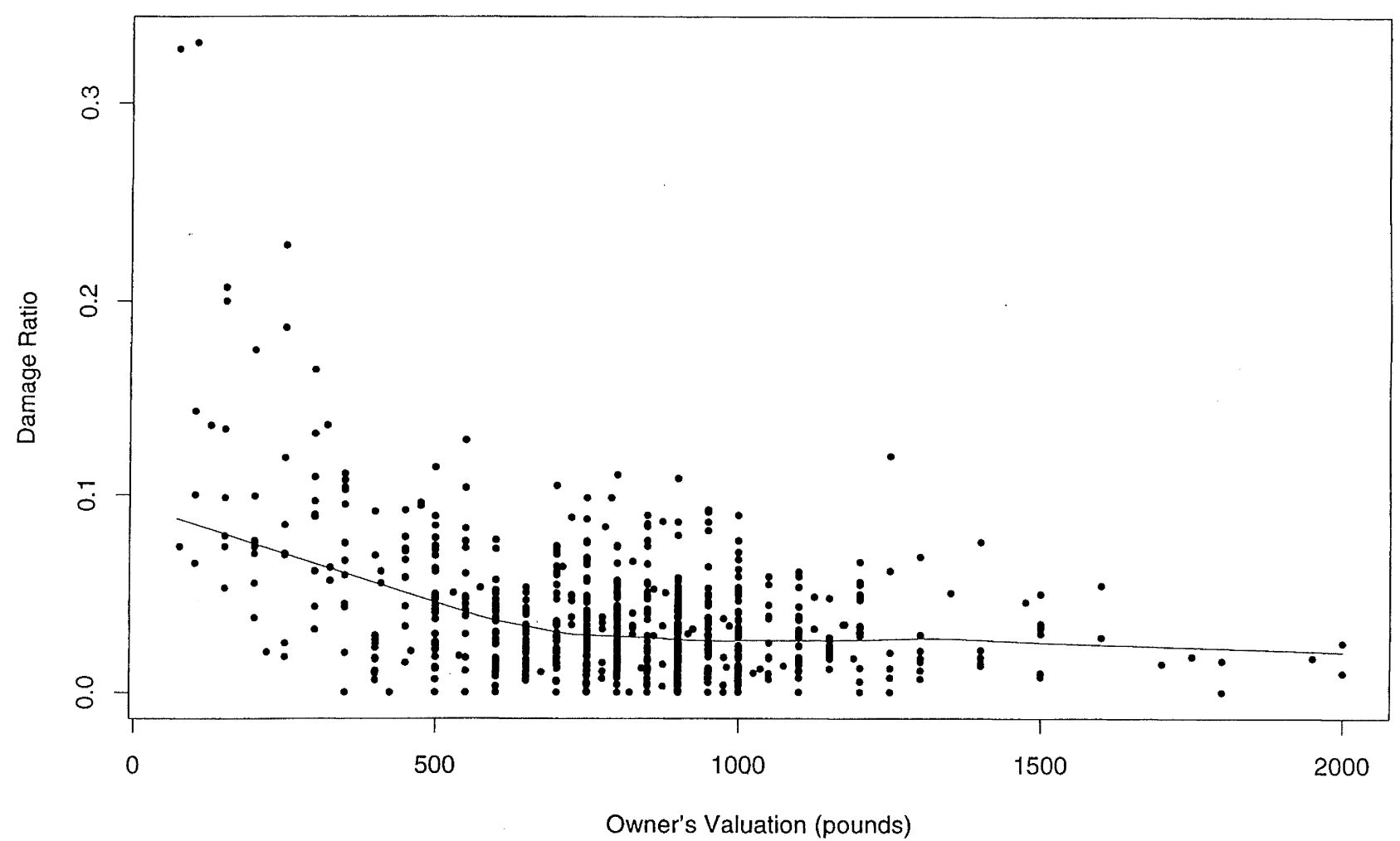

FIGURE 9 Plot of damage ratios versus valuation for single storey timber houses on soft ground (class 3) in Napier. A "robust fit" of the mean damage ratio curve is also plotted.

mean curve has been fitted. The subset for Figure 9 was chosen deliberately to be as uniform as possible, i.e. single storey timber houses on flat ground on a single ground class (soft ground without Ground Damage), so as to highlight any possible effects of house size. The mean damage ratio curve has been fitted (a "robust fit"), which shows that the mean damage ratio is insensitive to house Value (i.e. floor area) from a value of about $£ 700$ upwards. Below $£ 700$ the mean damage ratio rises as houses value decreases. This may in part be due to the apparent tendency for very small houses to be valued at less than the Replacement Value. Note that the mean house value is $£ 890$.

\section{NUMBER OF HOUSES DAMAGED VERSUS TOTAL NUMBER OF HOUSES}

It has been found here that for the MM10 zone of the 1931 Hawke's Bay earthquake nearly all houses (>99\%) sustained some damage, though the mean damage level was not great, and for the least damaged properties the damage was very slight For modern New Zealand houses, i.e. without brittle brick chimneys and with robust foundations, it appears that there would be an appreciable percentage of houses undamaged at intensity MM10, perhaps 10 percent.

These results for MM10 from 1931, are plotted on Figure 10 together with the percentage of houses damaged in the MM6 to MM9 zones of the 1987 Edgecumbe earthquake [8]. From this figure we see no apparent disparity between the trend (with increasing intensity) of the Edgecumbe earthquake results, and the results for Napier.

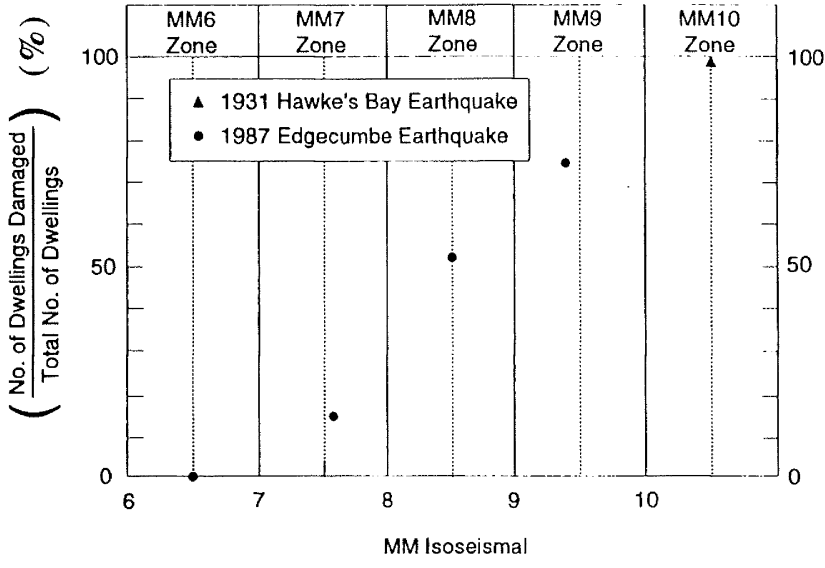

FIGURE 10 Number of cases of damage as a percentage of total number of houses as a function of intensity, in Napier in 1931 and in the 1987 Edgecumbe earthquake [8].

\section{REPRESENTATIVENESS OF THE DATA}

Our loans data give damage ratios for 2600 houses. This is a very large sample, being approximately three quarters of the total numbers of houses (c.3400) in Napier at the time of the earthquake. Statistically, this size of sample is bound to be representative if the sampling method is unbiased. A check on this involved use of the cost estimates from the Re-occupation data. We compared the costs of two sets of houses in the Reoccupation data set, (1) houses for which loans were obtained 


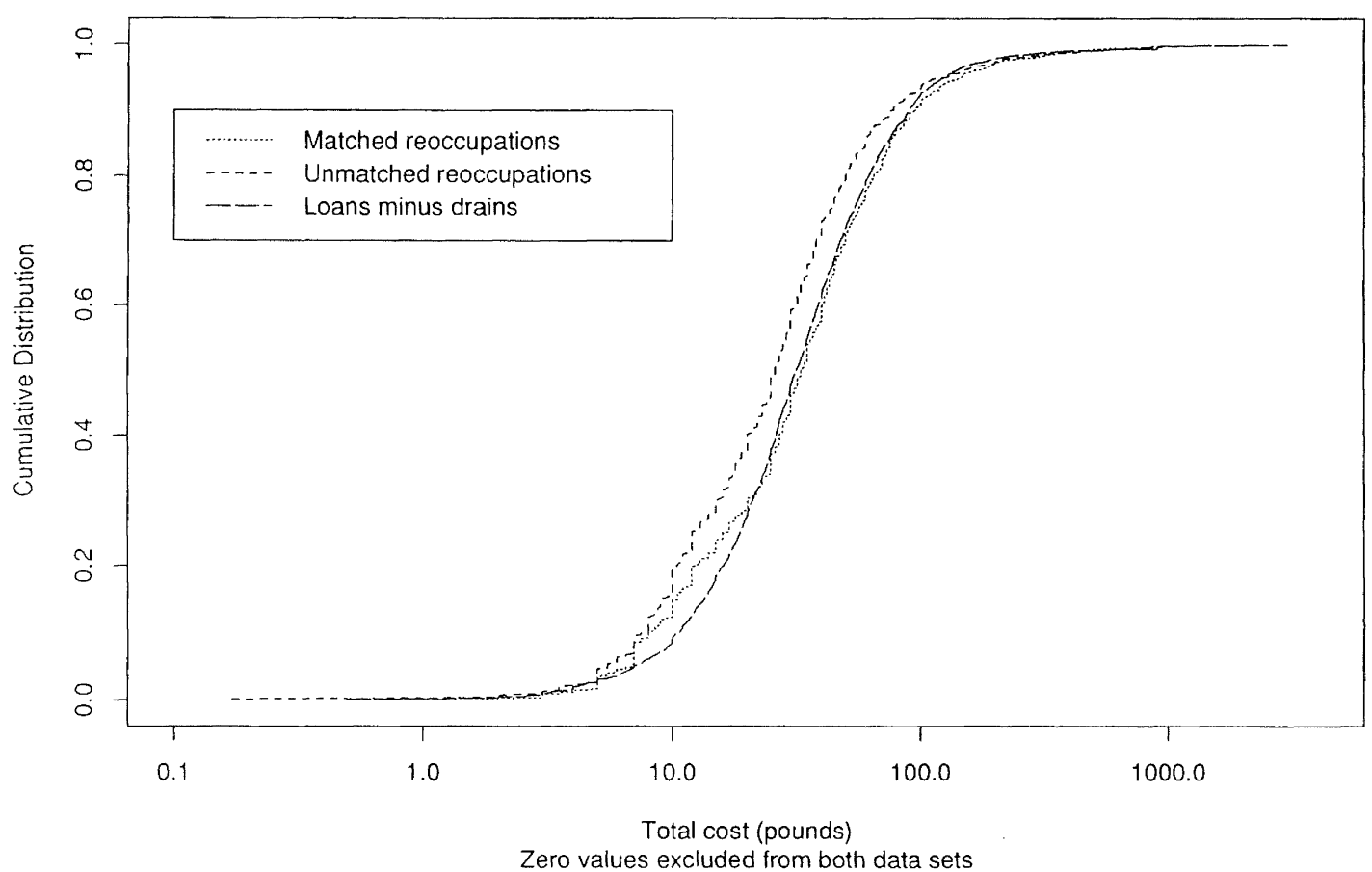

FIGURE 11 Cumulative probability distributions of costs from the re-occupation dataset for properties with loans (matched) and without (unmatched). Compared with the distribution of actual costs derived from the loans dataset.

for the repairs (matched), and (2) houses for which loans were not obtained (unmatched). The distributions of these two sets of houses were plotted (Figure 11) for comparison, and it is seen that the two sets of houses are very similar. The houses without loans are apparently slightly less damaged $(16 \%$ less damage) than those with loans. As noted earlier, our two data sets (Loans and Re-occupation) between them account for almost all of the houses in Napier.

In addition a considerable effort was put into identifying houses that were totally destroyed, and as noted earlier 14 such houses were added to the Loans data set. Some further houses (a dozen or so) were destroyed by fire, and these have been excluded from our analyses.

Overall we are confident that our main data set for damage ratio analysis is representative of the damage levels in Napier.

\section{TOPOGRAPHICAL EFFECTS}

The hill in Napier is a pronounced topographical feature, and may well produce significant enhancements of ground shaking at some locations. Because of the quality of our damage data set, the opportunity is being taken to carry out a major topographical study, which also involves wave modelling and microtremor studies. Amongst other things, it is hoped that this study will clarify the relationship between the strength of shaking on the rock and on the sediments. This extensive study is planned for 1994 to 1995 and will be reported on in a separate paper in due course.

\section{CONCLUSIONS}

Two sizeable sets of data on damage to houses in Napier have been assembled from original documents created in 1931 and
1932 after the magnitude 7.8 Hawke's Bay, New Zealand, earthquake. Based on studies of these data sets and other information, the following conclusions have been drawn:

1. The main database used in this study was for 2600 houses, data being derived mainly from applications for loans for repairs. The data was representative of the total of c. 3400 houses in Napier at the time of the earthquake.

2. Damage ratios and their statistical distributions have been estimated for house buildings, with various subsets of data being examined.

3. The Valuations of the houses given in the documents appear to equate to their Replacement Values.

4. For modern New Zealand timber houses, the mean damage ratios for a mixture of ground conditions are estimated to be $D_{r m}=0.08$ and $\bar{D}_{r}=0.07$. This assumes that half of the houses have brittle (brick) chimneys.

5. Considering different ground conditions, damage to house buildings was worst on sites having ground damage (significant subsidence and/or ground cracking). Next worst were houses on rock, but this may partly be due to topographical effects. Houses on firm beach deposits were less damaged than those on rock, while the least damage was experienced on soft ground. This implies that short period ground motion is attenuated by soft ground sites when the shaking is strong.

6. The percentage of houses damaged at intensity MM10 is about 99 percent, if all houses have brick chimneys and have the substructure weaknesses prevalent in 1931. It seems likely that perhaps 90 percent of modern New 
Zealand houses would be damaged at intensity MM10.

7. The damage ratios for houses at intensity MM10 were found to fit well to the lognormal distribution. The scatter was found to be less than that observed in the Edgecumbe earthquake, presumably because the construction styles in 1931 were more uniform than those of 1987 (notably there were fewer types of cladding in the 1931 housing stock).

8. The damage to house buildings was worst on sites with significant Ground Damage. This is likely to have been caused by differential ground displacements rather than higher accelerations.

9. The mean damage ratio for single storey timber houses is fairly constant in relation to house Value over most of the Value range.

\section{ACKNOWLEDGEMENTS}

The authors are indebted to many people and organisations for their assistance in this project, as follows. The Napier office of the Public Trust and the Hawke's Bay Cultural Trust (the Museum) for safely keeping the documents which made this study possible; the Hawke's Bay Cultural Trust (Museum) and the National Archives of New Zealand without whose special arrangements for using the documents this study would not have been feasible; the Earthquake Commission for their financial contribution to the considerable costs of this major study; Robert and Helen MacGregor for encouraging David Dowrick to visit the Museum in Napier to inspect its holdings on the earthquake; many residents of Napier who provided information or other assistance during the data gathering phase, especially the MacGregors.

We also wish to acknowledge the assistance provided in assembling the computer database by our colleagues Caroline Preston, Toakase Palu, Tina Steele, Sri Sritharan, Jim Cousins, Terry Porritt and John Zhao. Further we wish to thank Graeme McVerry for his constructive in-house review of this manuscript.

\section{REFERENCES}

1. Dowrick, D.J. 1991. Magnitude reassessment of New Zealand earthquakes, Earthquake Engineering and Structural Dynamics, 20:577-596.

2. Dowrick, D.J. and E.G.C. Smith. 1990. Surface wave magnitudes of some New Zealand earthquakes 19011988, Bulletin of the N.Z. National Society for Earthquake Engineering, 23(3):198-210.

3. Haines, A.J. and D.J. Darby. 1987. Preliminary dislocation models for the 1931 Napier and 1932 Wairoa earthquakes, N.Z. Geological Survey Report EDS114.

4. Dixon, C.E. 1931. Earthquake proves superiority of wooden buildings, Part I, N.Z. National Review, 45-58, March 15.
5. Dixon, C.E. 1931. Earthquake proves superiority of wooden buildings, Part II, N.Z. National Review, 45-61, April 15.

6. Brodie, A. and A.G. Harris. 1933. Damage to buildings, part of Report on the Hawke's Bay earthquake of 3rd February, 1931, The N.Z. Journal of Science and Technology, XV(1):108-115.

7. Dowrick, D.J. and D.A. Rhoades. 1990. Damage ratios for domestic buildings in the 1987 Edgecumbe earthquake, Bulletin of the N.Z. National Society for Earthquake Engineering, 23(2):137-149.

8. Dowrick, D.J. 1991. Damage costs for houses and farms as a function of intensity in the 1987 Edgecumbe earthquake, Earthquake Engineering and Structural Dynamics, 20:455-469.

9. Dowrick, D.J. and D.A. Rhoades. 1993. Damage costs for commercial and industrial property as a function of intensity in 1987 Edgecumbe earthquake, Earthquake Engineering and Structural Dynamics, 22:869-884.

10. - Hawke's Bay earthquake 3rd February, 1931, The N.Z. Journal of Science and Technology, XV(1):1-116.

11. Furkert, F.W. 1933. The effect of earthquakes on engineering structures, Minutes of Proceedings of the Institution of Civil Engineers, 236:344-68.

12. Dowrick, D.J. In preparation. Damage and intensities in the magnitude 7.8 Hawke's Bay, New Zealand, earthquake of 1931.

13. Smith, W.D. 1976. Statistical estimates of the likelihood of earthquake shaking throughout New Zealand, Bulletin of the New Zealand National Society for Earthquake Engineering, 9:213-221.

14. Dowrick, D.J. 1992. Attenuation of Modified Mercalli intensity in New Zealand earthquakes, Earthquake Engineering and Structural Dynamics, 21:181-196.

15. Standards New Zealand. 1992. Code of practice for general structural design and design loadings for buildings, NZS4203:1992.

16. Van Dissen, R.J., J.J. Taber, W.R. Stephenson, S. Sritharan, S.A.L. Read, G.H. McVerry, G.D. Dellow and P.R. Barker. 1992. Earthquake ground shaking hazard assessment for the Lower Hutt and Porirua areas, New Zealand, Bulletin of the New Zealand National Society for Earthquake Engineering, 25(4):286-302.

17. Steinbrugge, K:V. 1982. Earthquakes, volcanoes, and tsunamis - An anatomy of hazards, Skandia America Group, New York. 